\title{
Improving Rural Livelihoods in North East Kenya: Evidence of Sharia Cooperatives Outreach
}

\author{
Abd Elrahman Elzahi Saaid Ali ${ }^{1}$ \\ ${ }^{1}$ Islamic Development Bank (IsDBG), Regional Hub of Cairo, Egypt \\ Correspondence: Abd Elrahman Elzahi Saaid Ali, PhD, Islamic Development Bank (IsDBG), Regional Hub of \\ Cairo, Egypt. E-mail: aelzahi@isdb.org
}

Received: September 5, 2021

Accepted: September 27, 2021

Online Published: September 30, 2021

doi:10.20849/ajsss.v6i3.933

URL: https://doi.org/10.20849/ajsss.v6i3.933

\begin{abstract}
Sharia cooperatives (SACCO) are essential low-cost financing that helps underserved communities in Kenya through giving loans, savings, school fees, and considerable group lending. This research used both the structured questionnaires and Focus Group Discussion methods to investigate Sharia cooperatives providers and clients as the best means of financial inclusion to support the disadvantaged people in North-East Kenya (NEK) counties. Four dimensions of financing outreach including scope, cost, worth, and depth sharia cooperatives outreach have been studied. The results have shown Kenyans sharia cooperatives have not achieved a reasonable scope of outreach. This might be due to what is found in the study the lack of qualified sharia cooperatives staff and both financial and digital financial illiteracies of the clients. The clients were found to have low knowledge of their products and services, lack of using the internet and digital devices, and more than $80 \%$ of them undertaking transactions at the premises and preferred direct contact. Moreover, the results showed the investigated SACCO did not reach the optimal worth outreach Due to the increase in the number of underserved people and the high rate of poverty in the remote rural areas. The results also show SACCO in Kenya have achieved reasonable depth outreach since they are covered the underserved community members such as women, youth but need to exert still more efforts to reach the remote rural areas. Although the customers have seen the cost of sharia cooperative services is reasonable, the results showed the high cost of attracting new clients. That might be due to the unused of the targeted communities the new means of connections such as webmail, internet, and smart devices. Based on these results the study might recommend that these SACCO might need to implement effective training strategies to enhance clients and staff knowledge to improve financial and digital illiteracy to improve the scope, worth, and cost outreach dimensions. The results also show low depth outreach due to the poor basic infrastructures, lack of capital to adopt wireless finance to expand to remote areas. For this study might recommend more capital injection for SACCO to adopt digital financial technology. These results give good policy implication for the Islamic Development Institution (IsDB), Islamic financial institutions, investors, and other alike to help these sharia cooperatives through capital injection, financial awareness seminars, telecommunication companies, and building capacity programs to promote this low-cost financing for the most disadvantaged Muslim minority in Kenya.
\end{abstract}

Keywords: Shariah cooperative, scope outreach, worth outreach, depth outreach, cost outreach

\section{Introduction}

The history of cooperatives in Kenya dates back to 1908 when the Lumbwa Co-operative Society was established. For about two decades, the society was restricted to the settler (colonialist) population. In 1931 the first Co-operative Ordinance which did not allow Africans to participate in cooperatives was enacted primarily to regulate the operations of co-operatives by the government. A second Cooperative society ordinance was enacted in 1946 when the colonial government acknowledged that Africans needed to participate in the economy through co-operatives. In this year the Department of Cooperatives was established, and a Registrar appointed. The Swynnerton Plan paved the way for the formation of more co-operatives in 1954 when Africans began to be involved in the growing of cash crops. 1,894 societies had been registered by 1969, key examples of which were the Kenya Co-operative Creameries (KCC), Kenya Planters Co-operative Union (KPCU), Kenya Farmers Association (KFA), and Horticultural Cooperative Union (HCU). Priority was given to establishing a standardized accounting system in coffee and dairy farming, marketing cooperatives, and a system popularly 
referred to as Members Transactions (MT)followed by a savings and credit system integrated into the MT system. A retired Swedish banker, Sven Lindkvist, was hired to study the feasibility of introducing rural credit SACCO's linked to the marketing cooperatives. The scheme assumed his name and was known as Lindkvist Production Credit Scheme (LPCS). It was later renamed as Cooperative Production Credit Scheme (CPCS).

Lindkvist's study revealed that although cooperatives were the main sources of deposits for banks, it was difficult for cooperatives to get credit from the banks due to stringent, and what was considered discriminatory, lending policies. Members could not open savings or deposit accounts because of unrealistic minimum balance requirements. Lindkvist recommended that cooperatives start their own savings and credit system. This is how the standardized MT system became an enabler for the initiation of savings and credit systems for rural SACCO in Kenya. Initially, the CPCS was to use borrowed funds to lend to individual society membership. The MT system allowed members to migrate from cash receipts for their product to savings deposit accounts through their societies. The plan was to introduce and encourage a culture of saving in rural cooperatives. Society members were also encouraged to deposit surplus cash from other sources to build a pool from which to borrow and diversify their activities. The cooperative unions established savings and credit (union banking) sections to manage these activities. In many district cooperative unions, this activity developed into rural banking units, with huge savings and loan portfolios. When these developments were taking place, the establishment of the Cooperative Bank in 1965 was underway. The bank provided the momentum for the growth of the union banking units by lending to the societies. At the same time, the concept of creating a common bond between a Savings and Credit Cooperative Society (SACCO) with an employer was mooted. The Government also introduced subsidies and free access to government credit and free extension services. The year 2012, was dubbed The Year of Cooperatives, a crowning moment in Kenya's cooperative movement calendar. The International Cooperatives Alliance (ICA), which unites, represents, and serves cooperatives Worldwide, identified Kenya's cooperative movement as one of the most regulated in Africa and the best in East Africa. In July 2013 WOCCU recognized Kenya SACCO as the fastest growing subsector in the World.

Today, cooperatives in Kenya have made remarkable progress in sectors, such as agriculture, banking, credit, agro-processing, storage, marketing, fishing, housing, and transport. Emerging sectors, such as Information, Communication, and Technology (ICT), are leveraging on the demands of the traditional cooperatives to infuse innovation and technology in their operations. The sector may now be categorized into financial and non-financial cooperatives. The former dealing with the marketing of members' products and services such as dairy, livestock, coffee, tea, handicrafts while the latter comprises SACCO's, housing, and investment cooperatives. The SACCO industry does play a key role in financial deepening and intermediation in Kenya. The structure of the cooperative movement in Kenya places individual members at the bottom of a pyramidal organizational structure. The Cooperative Alliance of Kenya (CAK), formerly known as Kenya National Federation of Cooperatives (KNFC), is at the top as an apex body. SACCO's fall under the Kenya Union of Savings and Credit Cooperative Societies (KUSCCO) under a similar structure. The cooperative movement in Kenya is vertically organized into a four-tier pyramidal structure that links up primary cooperatives at the local (lower) level to the national (higher) level. The structure consists of primary cooperatives at the bottom, district/ commodity cooperative unions, national cooperative organizations, and one confederation, CAK, whose membership includes national cooperative organizations as well as some cooperative unions and primary cooperatives not affiliated to any union. It is through CAK that the Kenyan cooperative movement is linked to the World's cooperative movements.

Most of the primary cooperatives in Kenya have their origin in state-controlled promotion of cooperative development, which saw people join cooperatives not on the basis of their common bonds and mutual trust, but due to the directive from the state that compelled those engaged in similar economic activities to join specific types of cooperatives. For instance, in the agricultural sector, it became mandatory for cash crop farmers to join cooperatives in order to market coffee, cotton, pyrethrum, and milk. Kenya an established legal cooperative regulatory framework. Savings and Credit Cooperative Societies (SACCO) in Kenya are regulated by the SACCO Societies Regulatory Authority (SASRA) established in 2010 after the gazettement of the SACCO Societies (deposit-taking SACCO) regulations. Kenya has an independent regulator within the well-defined legal and regulatory framework. There are specific regulations for SACCO's that are the SACCO Societies Act and Co-operative Banking Act, respectively. The SACCO sub-sector can be described as two-tiered given the range of financial services to members and regulatory regime. The traditional Savings and Credit Cooperative Societies (SACCO's), described in law as Non-Deposit taking SACCO's provide a limited range of savings and credit products, are registered and supervised under the Cooperative Services Act, CAP 490. The Deposit Taking SACCO's (DTS) besides the basic savings and credit products, also provide basic 'banking' services (demand 
deposits, payments services, and channels such as quasi banking services through ATMs and Mobile banking. The general trend is that SACCO's start as a non-deposit taking SACCO business and grow to a deposit-taking SACCO business to expand the range of financial services to members.

Sessional paper No. 10 of 1965 on "African Socialism" gave impetus to rapid Africanization of Kenyan economy and poverty eradication based on principles similar to those adopted by the co-operative movement. Thereafter the first post-independence Government Co-operative Development Policy of 1966 saw the enactment of the Cooperative Societies Act (Cap 490). Sessional Paper No. 8 of 1970 main goal was the consolidation of the cooperative activities. This included improvement of the management of societies, intensification of education and training for members, committee, and staff with the provision of government support staff as supervisors. Another review of the Co-operative Development Policy took place in 1975 where the government continued to recognize co-operatives as vital organs for mobilizing material, human and financial resources for national development.

Sessional Paper No. 4 of 1987 on "Renewed Growth through the Co-operative Movement", reiterated its commitment to enhancing the participation of Kenyans in the economy through Co-operatives. The responsibility of organizing and managing co-operatives was left to the members and their management committees while the government played an advisory role. Sessional Paper No. 6 of 1997, on "Co-operatives in a Liberalized Economic Environment", the government reviewed its involvement in the management of cooperatives by providing a legislative framework under which co-operatives were to survive in a competitive economic environment. The National Poverty Eradication Plan launched in 1999, provided for a broad-based approach to economic growth, especially in the rural areas, with cooperatives being a key vehicle. The Cooperative Societies Amendment Bill of 2004 sought to re-introduce some degree of government control. This act prepared the new Co-operative Societies Rules, 2004. It also revamped the role of the Co-operative Tribunal Court, a specialized Co-operative Commercial Court, to fast track and speedily dispenses the backlog of cases. This is the first Tribunal of its kind in Africa and many countries are consulting on how to establish their own. Moreover, the SACCO Societies Act introduced prudential regulation of all deposit taking SACCO's was enacted in 2008. This act has paved the way for the establishment in 2009 of the SACCO Societies Regulatory Authority (SASRA) and the Cooperative Alliance of Kenya Limited (CAK) as the national apex organization for the cooperative movement in Kenya, following the collapse of the Kenya Federation of Cooperatives Union. CAK's mandate is to promote cooperative development, unite the movement, and represent the cooperatives' interests on all matters of policy and legal framework. CAK has been recognized internationally and admitted to Group 10 of the most developed movements globally. The Ethics Commission for Cooperative societies was established in 2011 to handle ethical and integrity issues. The commission works closely with the national anti-corruption agency to minimize losses occasioned by graft and recover all assets, including land and buildings of cooperatives that have illegally been acquired. As a result, by December 2013, there were over 6,000 registered non-deposit taking SACCO's in Kenya, 1,995 of which were active in the context of SACCO's that filed their audited financial statements with the Commissioner for Cooperative Development as a legal requirement.

Cooperatives played a vital role in Kenya's economic development. Kenya has the highest proportion, in percentage points, of GDP attributable to cooperatives globally, standing at 45 percent, followed by New Zealand with 22 percent. Kenya is ranked number one in Africa and seventh in the world on the strength of savings in excess of kshs 400 billion which is 35 percent of total savings. About 60 percent of the Kenyan population earn a living from cooperatives. There are now 3,280 SACCO's that account for about 60 percent, 64 percent, and 63 percent of the country's savings, loan, and assets respectively. The movement provides two million jobs with 70 percent of Kenyans depending directly or indirectly on cooperatives. The cooperatives movement in Kenya boasts of an annual turnover of Ksh 436 billion (USD 4.4 billion) equivalent to 45 percent of the national GDP. In their operations, the cooperatives have mobilized savings of over Kshs 230 billion and provided affordable credit of over Kshs 184 billion to members. The total number of societies and unions registered had a 5.4 percent growth, rising from 4,228 in 2011 to 14,990 in 2012. A total of 45 multi-purpose societies were registered in 2011 while the number of dairy societies increased from 313 in 2011 to 343 in 2012. SACCO's control over Ksh 250 billion. There are 1.8 million members with SACCO loans compared to 1.9 million people with bank loans. SACCO's have also established over 400 Front Office Services Activities (FOSAs) in both urban and rural areas providing basic banking services to over four million Kenyans - a number that compares favorably with the number of accounts in the commercial banking system.

Recovery of Ksh.3.8 billion in SACCO's remittances from employers by 2010 out of Ksh. 4.3 billion arrears that had been outstanding since 2004. SACCO had mobilized savings to the tune of Ksh.380 billion with an asset 
base of 493 billion as of 31st December 2012 savings mobilization in the SACCO subsector has been growing at the average rate of $30 \%$ per annum. Income to co-operators has increased, e.g. milk-from ksh.8 (USD .08) to ksh38 (USD0.38) per liter; coffee-from ksh.10 (USD 0.1) to ksh.140 (USD 1.4) per kg. There has been tremendous growth of the co-operative financial organization into giant financial powerhouses which surpass the normal commercial banks and other financial. Institutions. The Co-operative Bank of Kenya is the 3rd largest bank in Kenya, whiles the Co-operative Insurance Company of Kenya (CIC), is the 2nd largest insurance in Kenya and the only one of its kind in Africa. Value addition is being done by some co-operative societies for example the New Kenya Cooperative Creameries (New KCC), Githunguri, Meru Central, and Kenya Coffee Co-operative Exporters (KCCE)will continue value addition under Kenya' development plan -vision 2030 in order to control a larger part of the product value chain. Co-operatives are also playing a vital role in input supply and distribution. The Kenya Farmers' Co-operative Union (KFCU) will participate in bulk fertilizer importation and distribution using the existing infrastructure (stores, vehicles, and machinery) owned by co-operatives and unions. In order to address the problems of fragmentation and informality that exist in the supply chain, the government ministry will encourage linkages between the formal market operators (wholesale and retail hubs), e.g. supermarkets and producer cooperative organizations. There is also the development of Diaspora co-operatives (SACCO) - already the Ministry of Industry, Investment and Trade has promoted two Diaspora SACCO in the America and United Kingdom (UK) in order to tap enormous resources generated by this subsector to channel into the country's investment opportunities.

600 Matatu SACCO have been registered in order to streamline and promote viable investments in transport subsector in the country. With the country experiencing an acute shortage of housing, especially for the low-income segment of the population in urban settlements, the Ministry has promoted 440 housing Co-operatives. However, these housing programs have stagnated due to a lack of affordable mortgage facilities and long-term lending to assist in housing development. Besides poor planning, the high cost of construction and building material, and the complex land administration mechanisms discourage investors/cooperatives in committing funds for housing projects. The Ministry in collaboration with USAID has registered and supported 27 County Youth Bunge SACCO in order to engage the youth in gainful business enterprises. These SACCO have already mobilized Ksh. 10 million (USD 100,000) savings and loaned out Ksh. 7 million. (USD 70,000). In 2014 USAID injected Ksh.8 million (USD 80,000) grants in form of a revolving fund to this program.

\section{The Sharia Cooperatives Outreach in North East Kenya}

The government of Kenya considers the importance of incorporating Sharia cooperatives in the lending system to serve an important subgroup of the community living in North-East Kenya. Beside the institutionalize observance of Sharia compliance principles in co-operative development, the government also recognizes Sharia co-operatives as one of the important vehicles for realizing its medium-term and long-term economic and social development objectives. The current Sharia SACCO served around 20\% of the Muslim Population community in Kenya. In order therefore to promote and to tap investments from the Muslim community, the Industrialization Ministry has established Sharia-compliant co-operative by-Laws to roll out products geared towards this segment market. The Sharia-compliant co-operative policy announced officially in 2014 marks an important step in the Government's efforts to enable the Muslim Community to fully participate in the development of the country through the cooperative sector. It identifies challenges that Muslims face in joining co-operative enterprises and calls for a shift towards a more proactive engagement between the Government, Muslims, the co-operative movement, and other stakeholders in addressing them. The policy seeks to create an enabling environment for the full participation of Muslims in the cooperative sector through the establishment of an appropriate legal and institutional framework and the development of Sharia-compliant products and services.

The government is also looking towards institutionalizing observance of Sharia-compliant principles in co-operative development with the aim of creating a conducive business environment for Muslims. Other objectives of the new guidelines include; the development of appropriate products, mobilization of savings from Sharia observant communities and institutions, and building capacity on Sharia compliance to all stakeholders.

There are almost six Sharia Compliant Co-operatives registered in Kenya that participated in this survey-, Crescent Takaful SACCO (CTS), Taqwa SACCO, Ajewarji SACCO, Bilal SACCO, Della SACCO, and Raymah SACCO. These cooperatives are a good encouraging attempt by the Kenya authority to reduce the huge financing gap associated with the Muslim community in the country. Crescent Takaful SACCO (CTS), headquartered in Nairobi, became the first Islamic SACCO to run front office operations (FOSA), such as deposit-taking and lending in 2013. Likewise, Taqwa SACCO was established in 1998 and has 2000 registered members. Its products include a normal loan that is three times the shares held by a member, repayable within 36 months, school/college fees loan repayable in 12 months, Zakat management services for its members and 
Children savings account. In 2013/2014 Taqwa SACCO purchased 30acres of land at Konza (where Kenya's first techno city will be built) and divided it into 114 quarter acre plots. These were balloted to subscribing members. It is now offering for sale shares to its members of a prime property worth Ksh 250,000,000 (USD 25 million) in the Central Business District of Nairobi at the cost of Ksh100,000(USD 1,000) that will also offer FOSA services. Every member is also required to pay Ksh. 12,000 (USD 120) towards Taqwa SACCO share capital which stands at Ksh. 4,068,000 (USD 40,680) which has greatly boosted SACCO's expansion plan towards the formation of FOSA. Its membership is drawn from Government Ministries, NGOs, Parastatals, and the private sector.

Taqwa SACCO has a check-off system with the Teachers Service Commission and Kenya's Defense Force. Its expansion project is the opening of FOSA branches North Eastern, Eastern, and the Coast of Kenya. As reported in its Annual General Meeting of 2012 Taqwa SACCO recorded an overall increase in turnover of $71 \%$ to Ksh $1,273,400$ (USD 12,734) - from Ksh 740,800(USD 7,408) in the year 2010. The members' deposits rose by $11 \%$ to stand at Ksh 35,434,811(USD 354,348) up from Ksh 31,694,900(USD 316,949) in the year 2010. On the other hand, loans to members, balance rose from Ksh 30,509,203(USD 305,092) in the year 2010 to Ksh 39,903,328 (USD 399,033) which accounts for an increase of 31\%. Bilal SACCO on another hand, was started 15 years ago. It has 4 branches in Mombasa, Kwale, Shimoni and Kibwezi. All its staff are on a contract basis or hired on a need basis. Bilal SACCO has a special product for women called the 'Jiko Plan' which helps women to buy Jiko (cooking stove). The unique thing about Bilal SACCO is that it offers a return on savings which may SACCO's do not do. Fourthly, Ajewarji SACCO is said to have been in existence for 4 years. It has 2 branches both of which are located in rural areas. It has 100 members. Moreover, Della SACCO was established $2 \frac{1}{2} 2$ years ago. It has 6 branches two of which are in the rural area. It has 15 permanent staff members and 183 members. Finaly, Rayma SACCO has been in operation for 2 years. It has 5 permanent staff members, no rural branches, and 60 members.

\section{Scope of Outreach}

Most SACCO in Kenya were reported to have been in operation average between 3-20 years. All the SACCO have average of small permanent staff and few branches which located either in outskirt cities or rural areas or both. The total number of clients ranges on average from minimum 900 up to 10000 out of which active accounts are only $50 \%$ or less of each SACCO clients are active. Most of the members learned about the SACCO from family and friends, followed by agent (26.7\%) and then through SACCO's marketing initiatives (20\%). Mosques were also reported by $20 \%$ of the respondents to be playing a role in the dissemination for almost all SACCO's information. No reports of the use of mass media and SMS Messaging service were made (Figure 1)

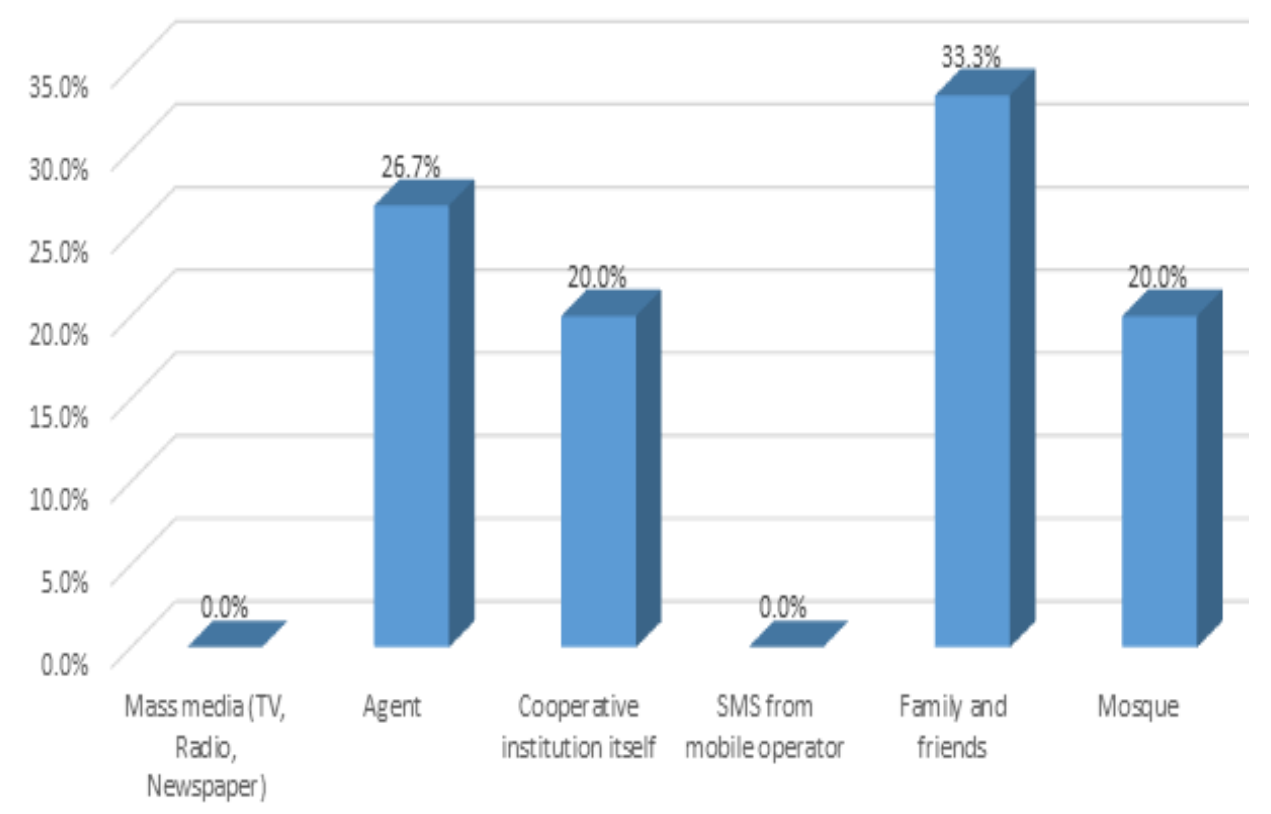

Figure 1. How respondents heard about sharia cooperative services 
However, $50 \%$ of SACCO members indicated that they prefer person to person interaction as a mode of the way of communicates with them. SMS messaging service and Mail was the preference of only $20 \%$ of the respondents. Telephone calls were the least preferred mode of communication at only $7 \%$. (Figure 2)

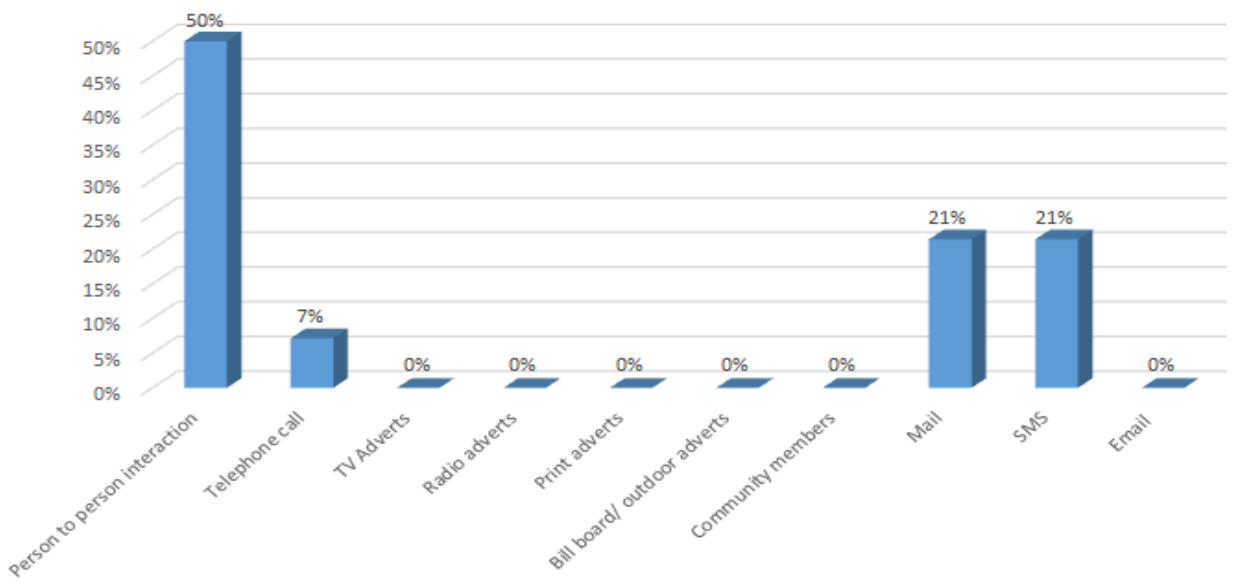

Figure 2. Preferred means of communication

Most of the respondents rated their knowledge of SACCO products and services as low while the knowledge of their staff on the same was rated as high. Most of the SACCO' staff reported that products and services could be accessed through the branch, mobile, and representative office (agent). Almost all the SACCO member respondents reported being able to use mobile phone devices but had issues with knowledge of the internet and its applications. The use of the ATM machine and Debit card did not fare well either and only 59.9\% were aware of agency banking (Figure 3). This could perhaps explain why most of the SACCO members reported undertaking transactions at the branches/bank tellers while $13.3 \%$ made use of the mobile phone and no mention of agency banking was made.

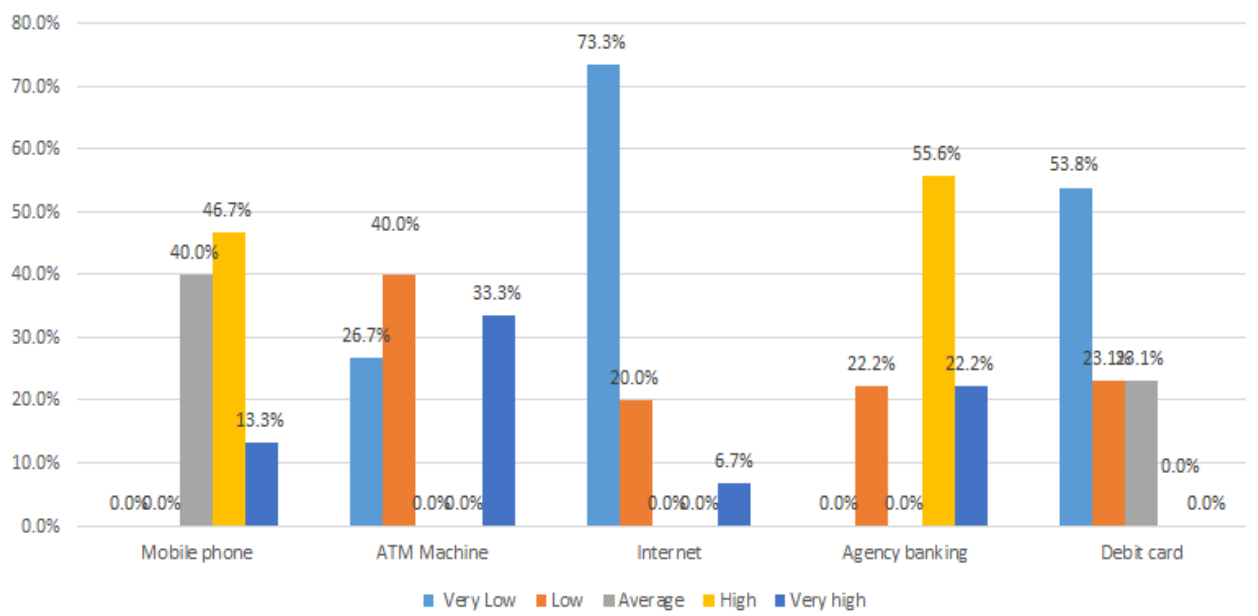

Figure 3. Respondents ability to use various devices

The types of transactions typically undertaken were listed by SACCO Members were savings (66.7\%) and loans $(20 \%)$. Chama (group) savings advance against expected harvest or livestock product and insurance products were not listed as transactions that could be undertaken at SACCO. (Figure 4) 


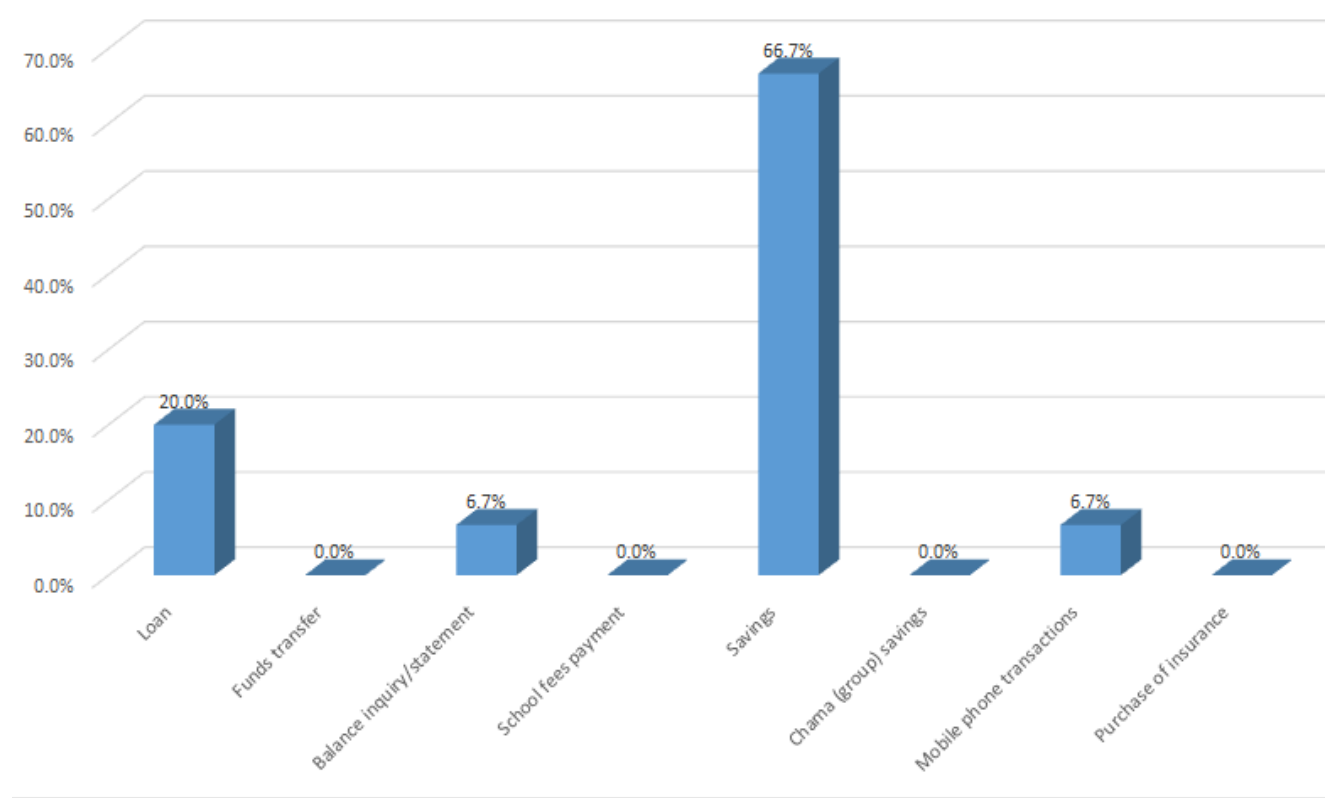

Figure 4. Types of transactions typically undertaken

Most of the SACCO members reported that it takes at least 3 days for a loan application to be considered and approved while few members said it took up to 4 weeks. However, a total of $26 \%$ of the SACCO members indicated that loan approval takes a maximum of two weeks. (Figure 5)

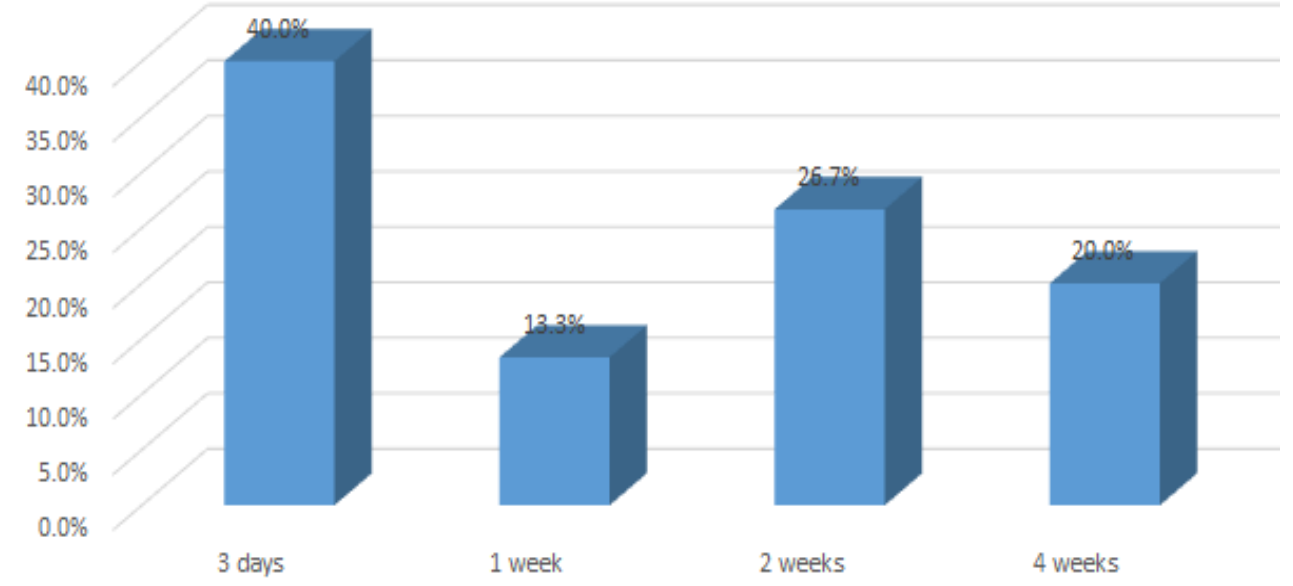

Figure 5. How long it takes for a loan to be approved

The loan processing period was reported to be almost a week by all SACCO staffs which is in line with the above members' response SACCO staff indicated that the average loan amount was between Ksh 250,000(USD2, 500) and Ksh 300,000(USD 3,000). The maximum loan amount to an individual and a group at any one time was found to be Ksh 1,800,000 (USD 18,000) and Ksh 1,000,000 (USD 10,000) respectively. They also indicated that SACCO do require collateral to secure its loans, which can be in the form of assets, stock, or co-guarantors. Loan amounts as reported by SACCO members on average ranged from Ksh 10000 (USD 100) -Ksh 5,000(USD 50 ) while $60 \%$ of the respondents reporting taking loans above Ksh 100,000(USD 1,000) (Figure 6) 


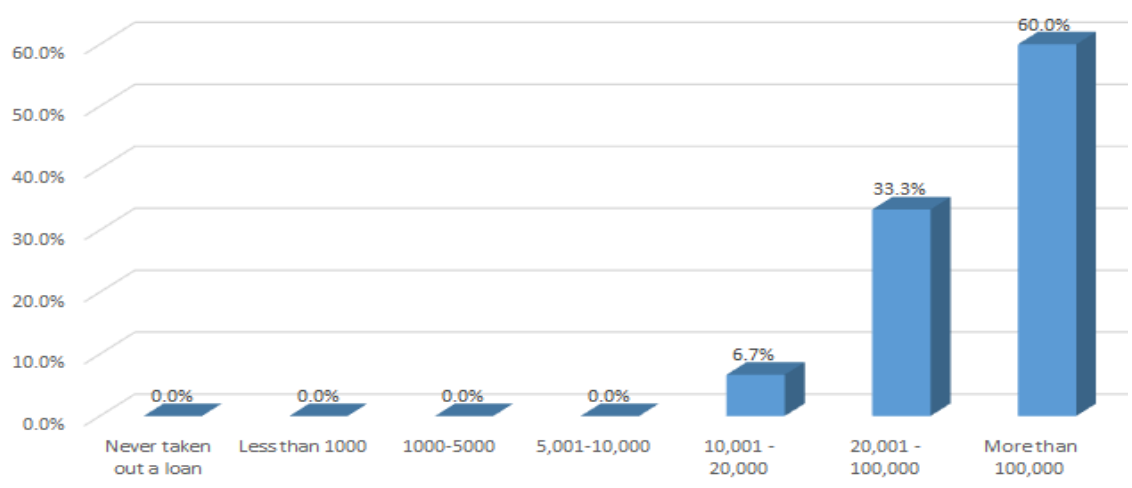

Figure 6. Typical amount of loan taken

Most of the respondents reported making monthly loan repayments of between Ksh 5,000(USD 50) to Ksh 20,000 (USD 200. Moreover, 20\% of the respondents reported making monthly payments of above Ksh 20,000(USD 200) (Figure 7). Most of the SACCO' members were reported these loans to be used to start a business, pay school fees and small amount used for construction.

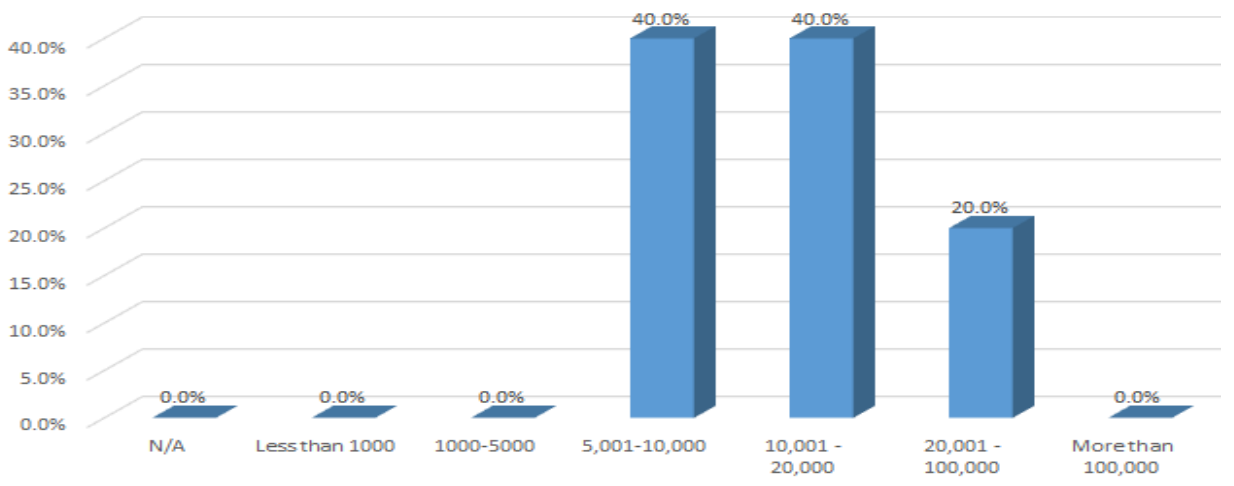

Figure 7. Typical monthly repayment

The typical maturity for the loan was reported to be 6 months by $60 \%$ of the respondents however there less than $7 \%$ the respondents reported loan maturities of 24 months (Figure 8). This would perhaps indicate that the longer-term maturity loans were used for construction purposes while the short-term loans could cater for school fees and business purposes. 


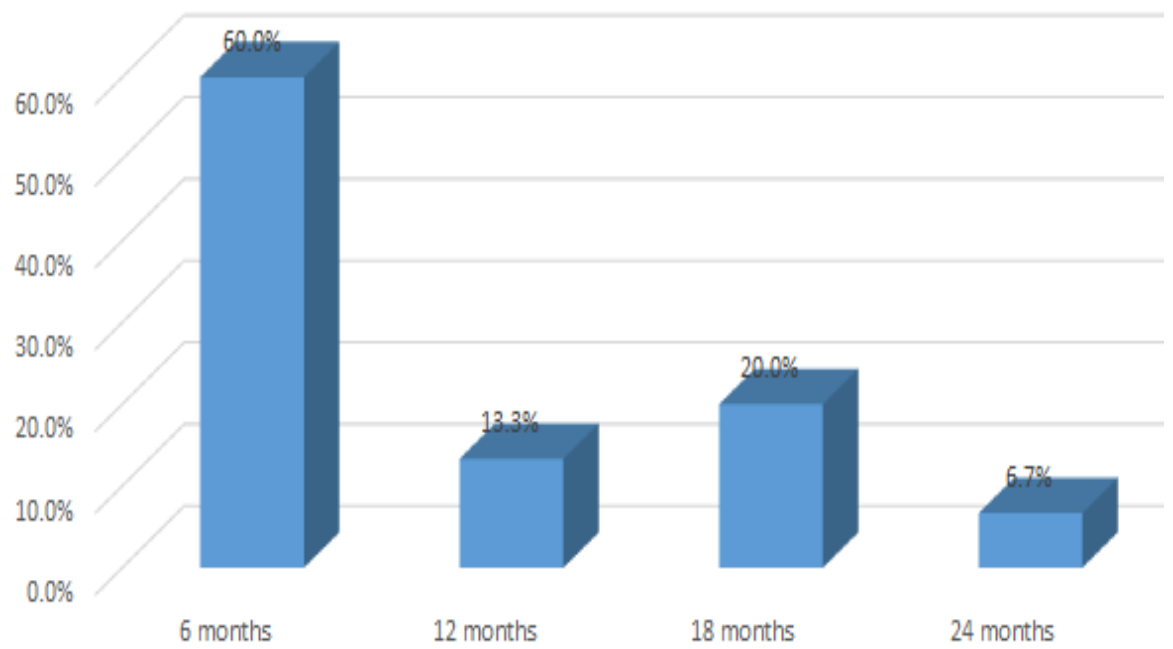

Figure 8. Typical maturity of the loan

Savings per month ranged from Ksh 1000 (USD 10) -Ksh 5,000(USD 50) for 60\% of the respondents and Ksh 10,000 (USD 100) to Ksh 20,000 (USD 200) for 20\% of the respondents. (Figure 9) The typical savings amount per month as reported by SACCO' staff is Ksh 5,000. These savings earned no return as reported by almost all SACCO' members.

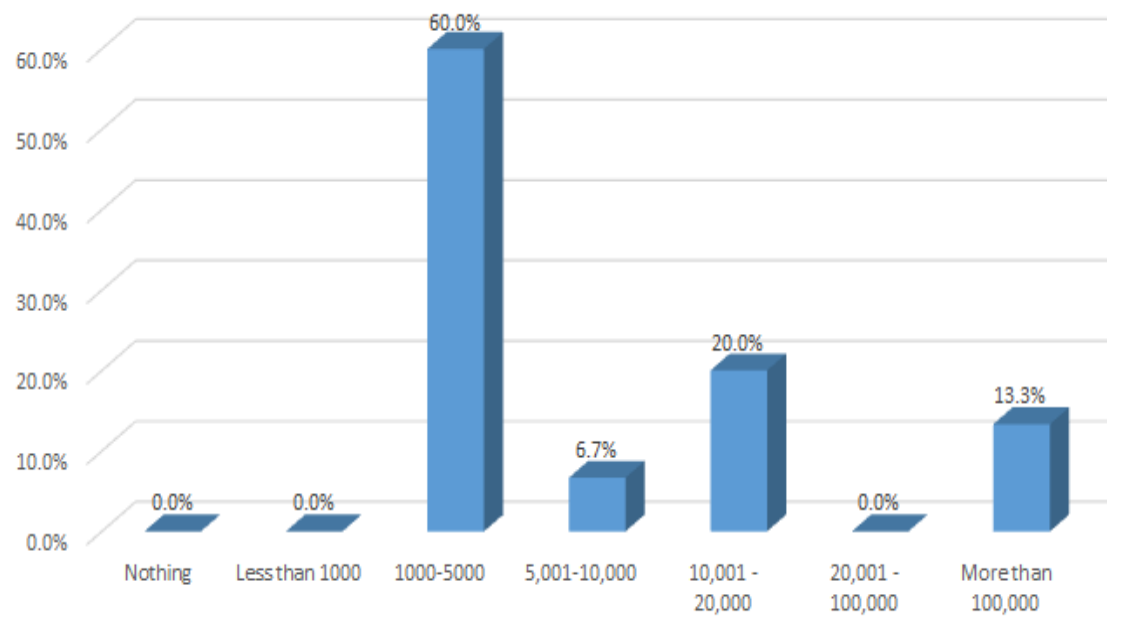

Figure 9. Typical amount of savings in a month

Interestingly with regards to new product offerings, $26.7 \%$ of the respondents asked for the introduction of Annual General Meeting, emergency loans, Insurance, and 24-hour service were requested by $20 \%$ of the respondents. ATMs were ranked last with only $13.3 \%$ of the respondents deeming them as necessary. (Figure 10) 


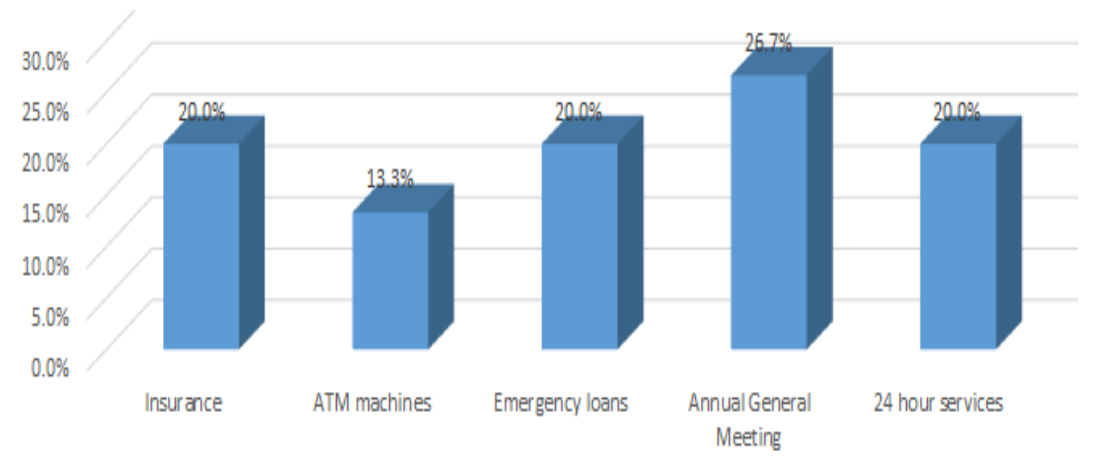

Figure 10. New products members wish can be offered

\section{Worth of Outreach}

$53.3 \%$ of the respondents reported operating their businesses less than a kilometer away from SACCO branches with $20 \%$ did report to being stationed between 5-10km away. (Figure 11) As to whether distance affects the way they transact with SACCO, $40 \%$ of the respondents confirmed that it did. However, $66.7 \%$ said this factor did not influence

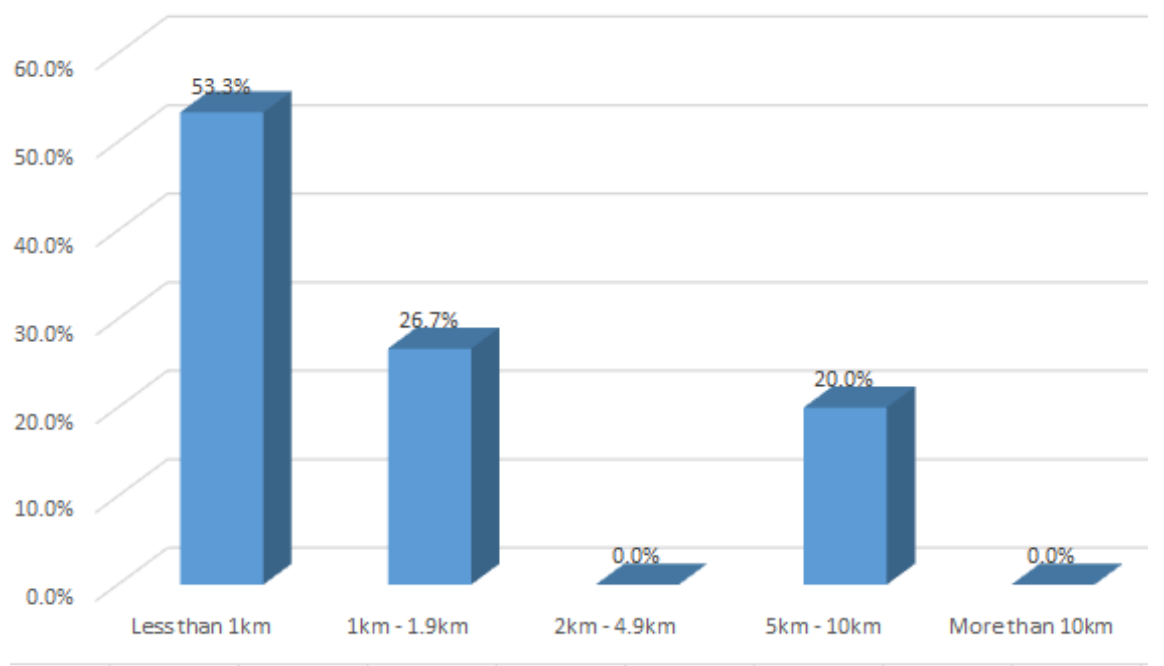

Figure 11. Distance of cooperative branch to place of business

All the SACCO were claim by its staff members to have the correct human resource and the right financial mix to achieve most of its goals but required a capital injection to increase its product suite, reduce the cost of operations, expand to the rural areas and enhance confidence. Religious reasons were ranked poorly as a prompt for choosing to become a member of SACCO when compared to security from fraud, opportunity to save and invest, lower transaction costs that were ranked 1 st, 2 nd, and 3rd respectively by the members. (Figure 12) 


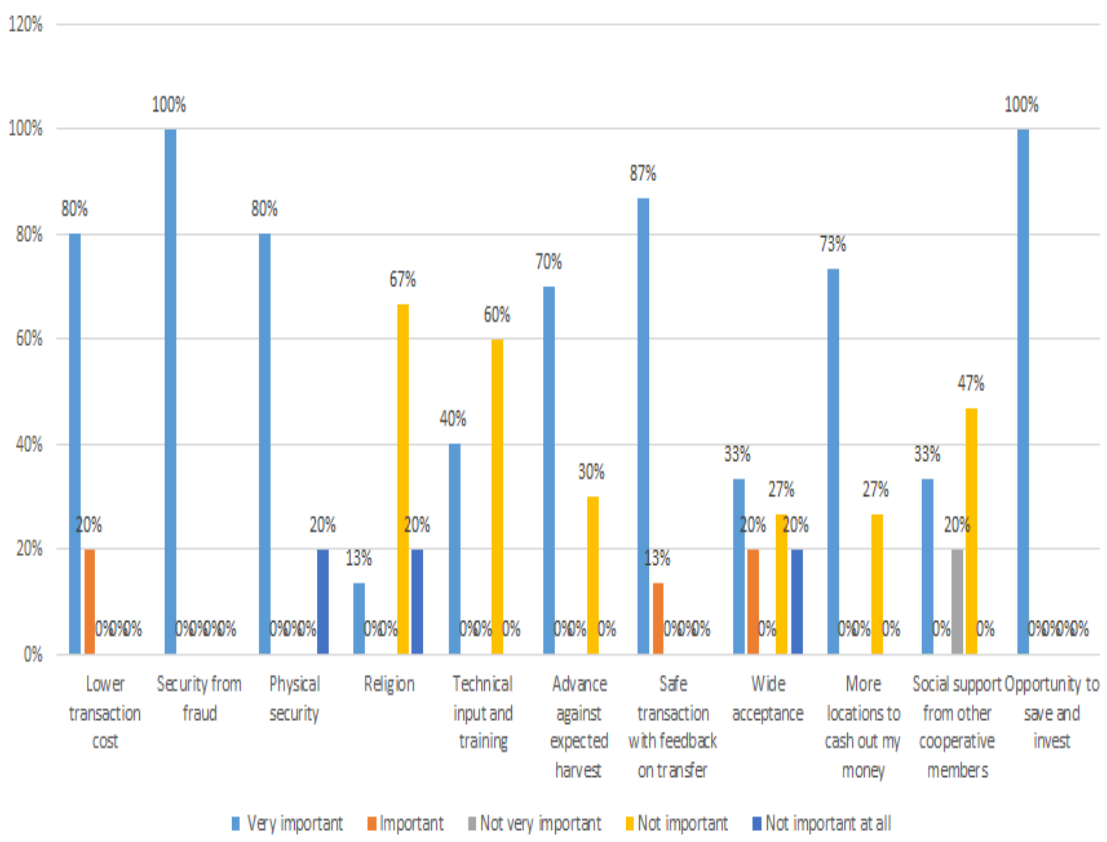

Figure 12. Reasons for using Sharia Cooperative

\section{Depth of Outreach}

Most SACCO Staff reported that $50 \%$ of their clients were women while the youth represented $20 \%$. Farmers and livestock farmers were reported to be $10 \%$. The number of rural poor accounts held were $16 \%$ out of the total accounts; only less than $2 \% 100$ of which were active. SACCO staff also did list Chama (group) and livestock products as components of the suite of products offered by their institutions, yet these were not listed by any of the SACCO member respondents. With regards to the question of whether SACCO target the rural poor, women, youth, and farmers, 53.3\% of indicated that SACCO products were not targeted at the youth, women, or farmers. $33.3 \%$ of respondents also indicated that that the very poor were also not targeted. (Figure 13)

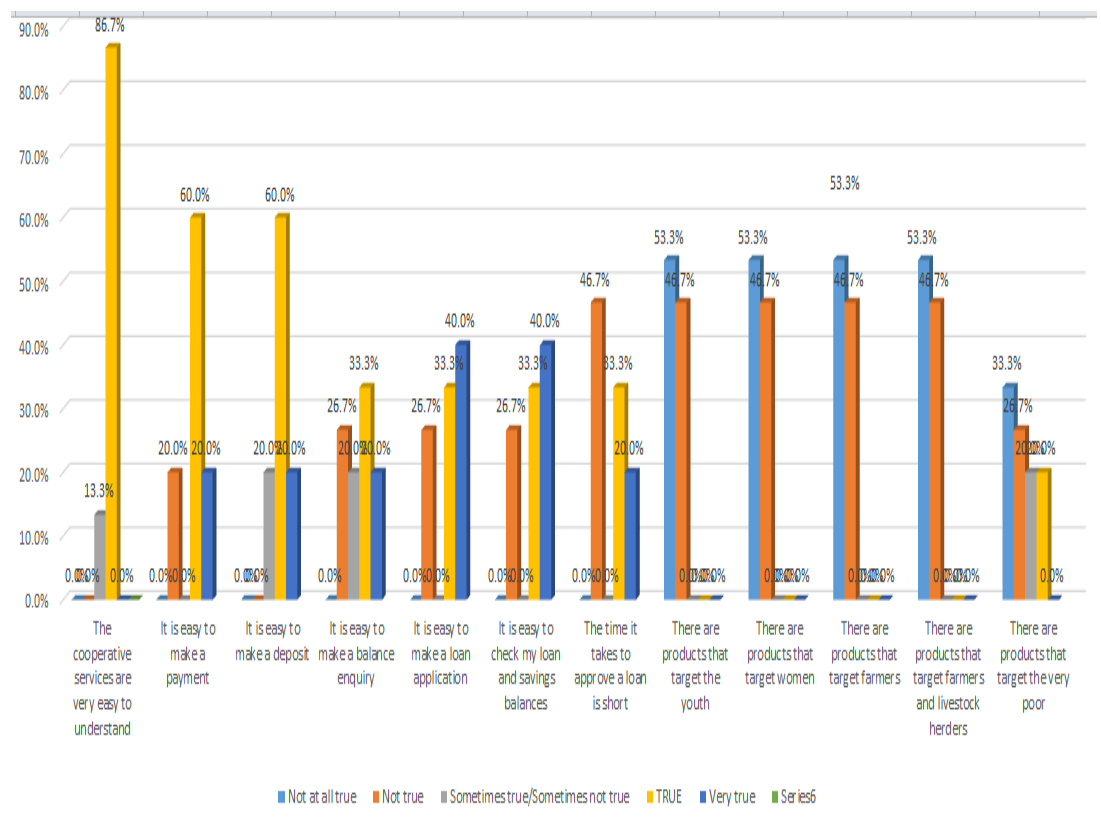

Figure 13. Respondents perception of cooperative services 
A reason for this difference in opinion could perhaps be due to the fact that products targeting the youth, women, and farmers were in the early stages of being rolled out as reported by SACCO staff members or inability of the SACCO to reach the depth due to low capital. The number of active borrowers was reported to be relatively low with few voluntary savings members. It is important to note that $53.3 \%$ of SACCO members reported holding both a savings and loan account; while $46.7 \%$ reported holding only a savings account. The ratio of outstanding deposits against loans was reported by SACCO staff to be on average Ksh 35,000,000 (USD 350,000) against Ksh 12,000,000 (USD 120,000). While SACCO staff members reported that it did not have enough capital to reach the required depth of outreach and the options available with regards to increasing their capital were commercial borrowing, development financing, capital injection, and deposit mobilization. However, it is only the Government of Kenya 'Youth /Uwezo 'fund' that was listed as a government or donor funding program that could be beneficial to SACCO and not deposit mobilization which would have seemed to be the easier option.

\section{Cost of Outreach}

Almost all SACCO' Staff indicated that their products and services were cheaper in comparison to conventional cooperatives and other Islamic Financial Institutions. This agreed with client's respondent who unanimously claimed that Sharia cooperative services were cheaper and less complicated than Islamic Banks products and services. More specifically more than 50\% of SACCO members cited its loans to be very cheap and the application process to be simpler than that of the Islamic Banks. Further, most of the respondents did acknowledge that it was easy to access SACCO products and services. As far as pricing of services was concerned SACCO' Staff indicated that what was not working well was the underpricing of products and services and that this could be improved by increased marketing and pricing. Furthermore, SACCO' staff reported that it was expensive to send out information to attract new clients, but they did acknowledge getting referrals from existing clients. They also indicated that the use of a mobile phone could reduce the cost of sending out this information. As to the question of affiliation with other institutions was concerned - some SACCO was cited unanimously by its members to have a need for beneficial affiliations that would improve technology and increase SACCO' product suite. Some SACCO Staff indicated that the institution did have affiliation with Takaful Insurance of Africa, CAK, and KUSCCO. They also reported that SACCO were regulated by the Commission of Cooperatives and that these affiliations did not make their products and services costlier. No affiliation to Islamic Bank or mobile services provider was reported; however, SACCO staff did indicate that there is a need for strategic alliances and partnerships. It is worthy to note that the affiliation to Takaful Insurance of Africa should have ideally been reflected in SACCO particularly with CTS product offerings in the form of an insurance product, but it is not. SACCO' staff members indicated that other sharia cooperatives, MFIs, Islamic Bank, and conventional cooperatives were the main competitors. Therefore, how and whether affiliations, strategic alliances, and partnerships that are beneficial in terms of improvement in technology, capital investment, and increase in product suites can be put in place and executed with perceived competitors remains to be seen.

\section{Summary Results}

The number of sharia cooperatives (SACCO) members in Kenya ranged from $60-3500$ per cooperatives. In general, all respondents reported having heard about the SACCO's from family and friends although mass media was also reported to be in use. This is in contradict to the respondents' preference for person-to-person interaction perhaps a factor of the limitation of staff numbers. Knowledge of products and services varied from low to high while the most cited types of transactions undertaken were savings and loans. Savings amounts were on average reported being between Ksh. 1,000 - Ksh. 5,000 while loans ranged from as low as Ksh10, 000 to Ksh 600,000. New products that the respondents would like to be introduced were ATMs, Annual General Meetings, and Emergency Loans, and 24-hour services. Sharia Cooperative products and services were claimed to be cheaper and less complicated in comparison to conventional cooperatives and other Islamic Financial Institutions. Distance, in general, does affect the way members transacted but it did not influence their decision of whether to join the SACCO or not. Much in the same way religious reasons were generally not cited as a prompt for becoming a sharia cooperative member.

The oldest participating SACCO is Taqwa SACCO which has been in existence for 20 years. Della SACCO and Raymah SACCO have the highest number of clients served /permanent staff ratio while Crescent Takaful has the lowest active account/total clients served ratio. Ajewarji and Raymah SACCO's are the only ones that have a rural presence and Taqwa SACCO is based entirely in urban areas while Crescent Takaful and Della have both urban and rural outreach. (Figure 14). 


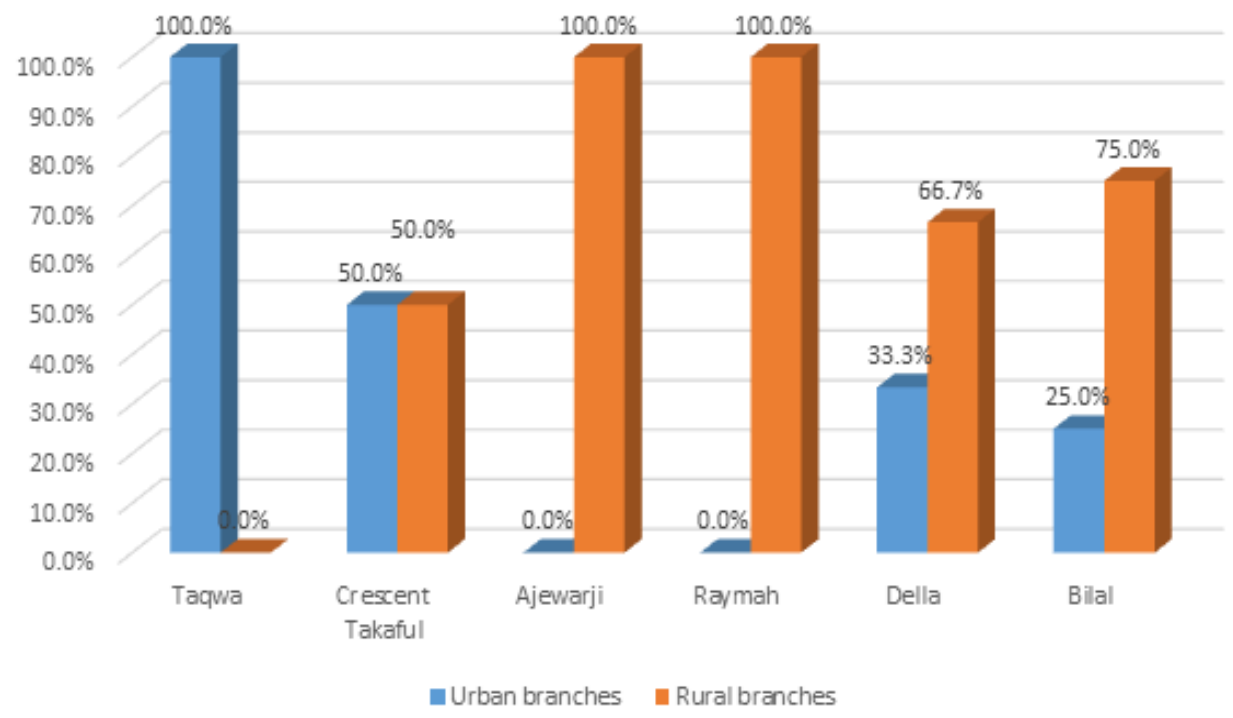

Figure 14. Number of rural branches as a percentage of total branches

Figure 15 provides details about the loans and savings products that are on offer from the participating SACCO's. Bilal SACCO has the highest number of active borrowers and it is the only SACCO that was reported to be offering a return on savings yet interestingly it has the least number of voluntary savings accounts. It also indicates the acceptable types of security for loans by the participating SACCO's. Land, Pay-slip, guarantors, and cattle were reported to be the most acceptable forms of security.

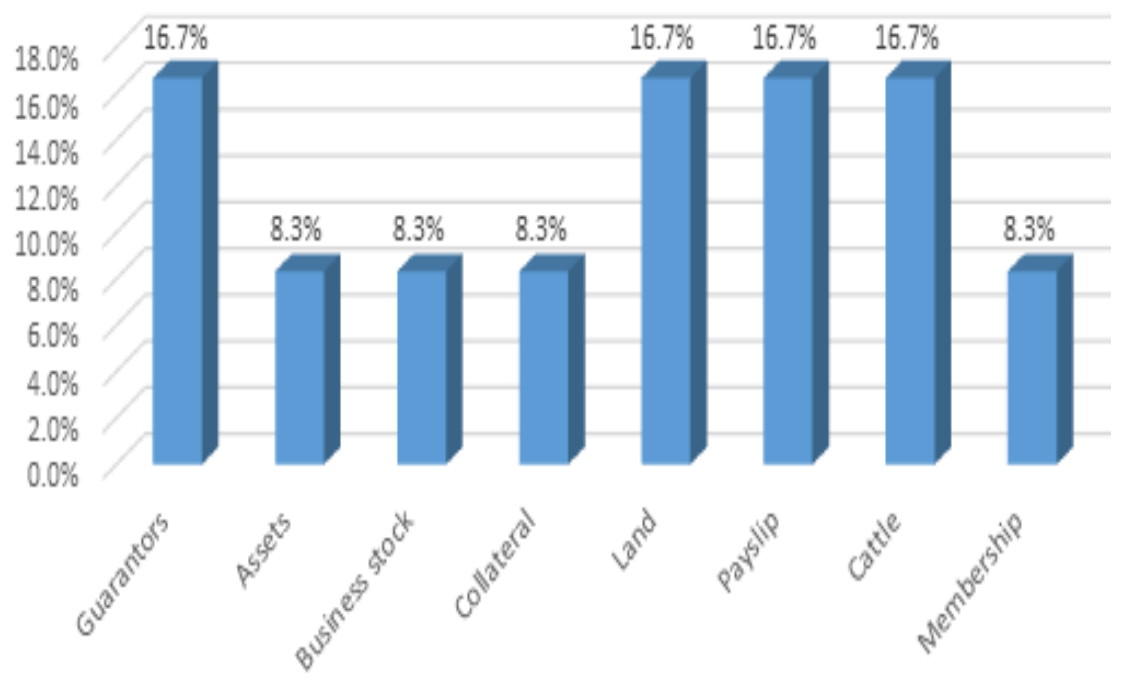

Figure 15. Acceptable types of security for SACCO Loans

Figure 16 indicates that the Sharia Cooperative in Kenya used the highest-rated applications of additional capital to expand their outreach to the rural areas, an increase of product suite, and donations to the poor which can be interpreted as consumption support. This might imply that SACCO in Kenya attempt to have a greater impact on the community by outreaching the poor and people live in remote areas as well as outskirt of the urban cities. 


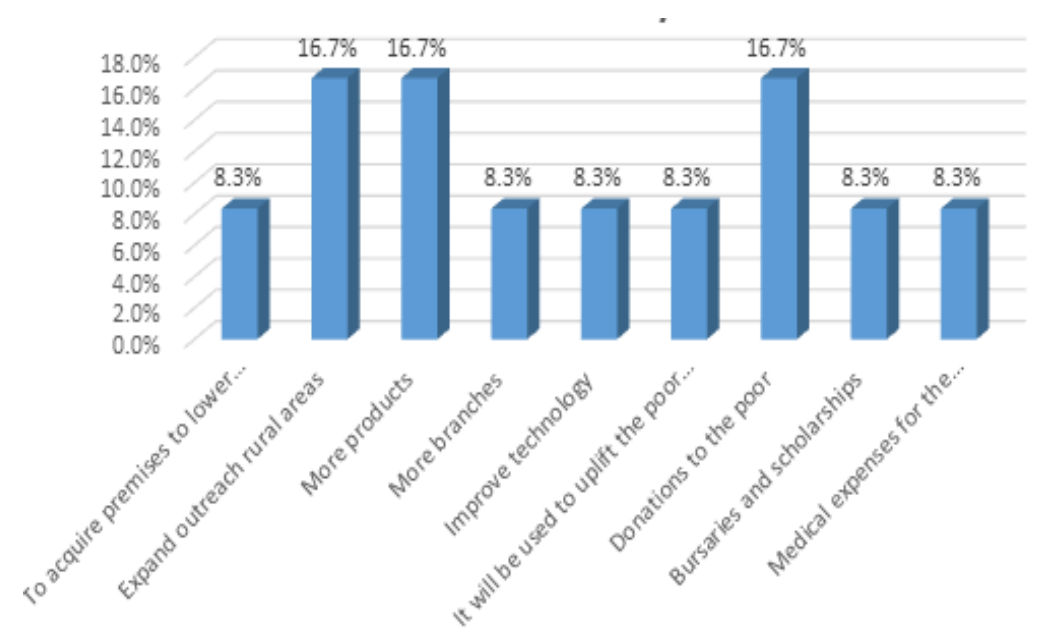

Figure 16. Application of additional capital to create an impact for the community

$75.2 \%$ and $21.8 \%$ of the SACCO members indicated that SACCO services and products are cheaper and less complicated than bank services and products respectively. Only 3\% of all the member respondents indicated that there was no difference (Figure 17). 14\% of the SACCO members reported that Islamic Bank loans were cheaper than Sharia SACCO loans. This shows the important role played by Sharia Cooperative services in serving excluded and underserved people such as low income, poor, youth, and women.

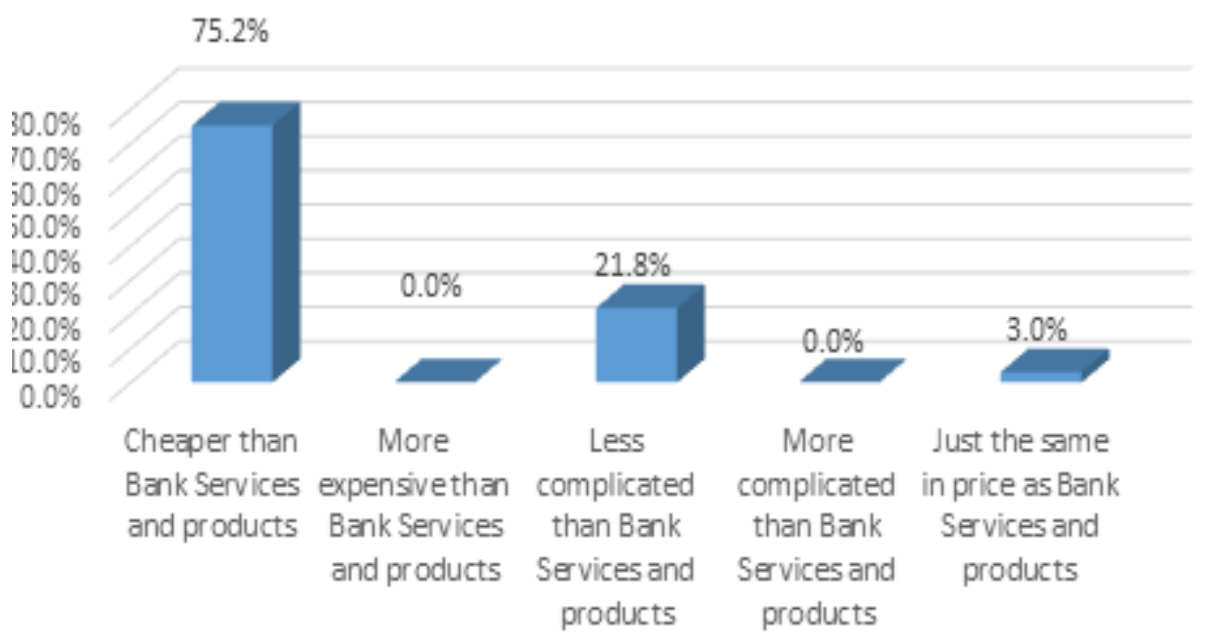

Figure 17. Comparison of perception of Sharia Cooperative and Islamic Bank Products and Services

Most of the SACCO member respondents indicated that the loan application process and requirements for sharia cooperatives were simpler than those of Islamic Commercial Banks. Moreover, the investigated sharia SACCO members indicated that their SACCO did not have any strategic affiliations and partnerships although they did concur that this would be beneficial to their SACCO as indicated in figure 18. Hence, this the study might recommend that further research into the identification and the implementation model of strategic alliances between Sharia SACCO and other stakeholders are undertaken as well as define possible merger, acquisition scenarios. 


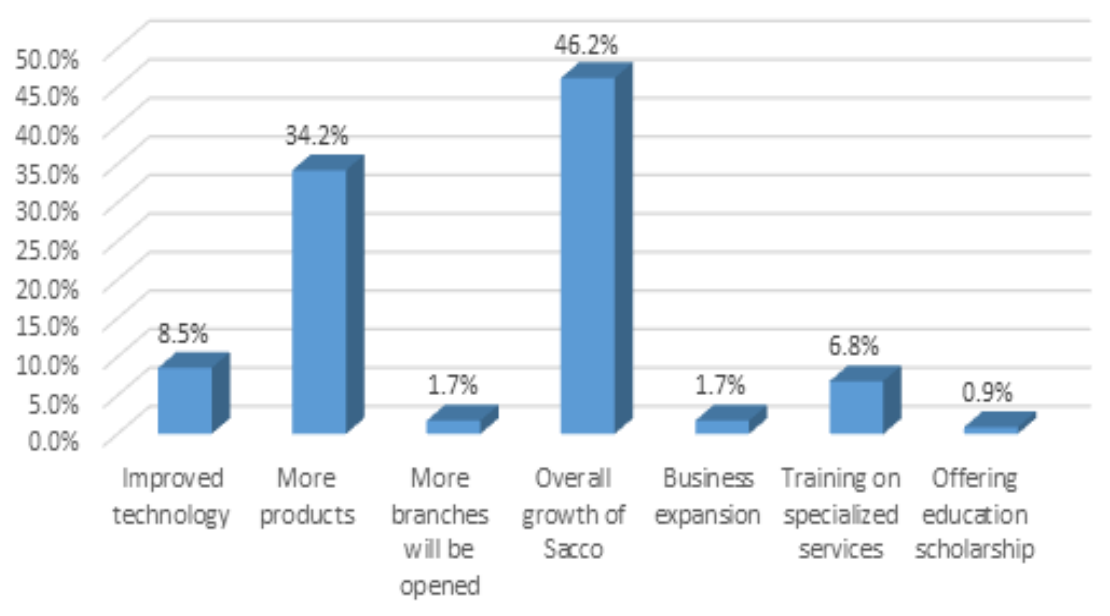

Figure 18. How would an affiliation be beneficial to the Sharia Cooperative

\section{Conclusion, Implications and Recommendations}

The results of this research imply that the investigated sharia cooperatives in Kenya are very essential in terms of the types of transactions they are covered such as loans, savings, school fees, and very low group lending. Despite that, the lack of qualified sharia cooperatives staff represents the big challenge affecting their scope outreach as well as the financial illiteracy of the clients. Moreover, the results show that almost more than $80 \%$ of the sharia cooperatives' customers undertaking transactions at the premises against very lower percentages of using mobile banking which might imply high transaction costs for the customers. Most SACCO customers more prefer direct contact than using SMS or phone banking and this might be due to illiteracy in using these means of communications. The results also show these sharia cooperatives customers have low knowledge of their products and services and lack of using the internet and digital devices despite their ability to acquired them. This might imply also digital financial illiteracy which must be addressed in order to enhance the scope of outreach, particularly for the remote rural areas. Hence, this study might recommend that these SACCO might need to expand its outreach by moving towards digital financial series in terms of financial technology adoption as well as customers digital financial capacity building. This calls for the need for financial education. Financial and Fintech skills education will help underserved people to achieve a better understanding of the credit system and increase their chance to have loan requests approved. In term of the worth outreach, the results of this study showed on average, religious and lower transactions cost ranked the main reasons for choosing a member of Sharia cooperatives. Due to the increase in the number of underserved people and the high rate of poverty in the remote rural areas, sharia cooperatives in Kenya are facing more challenges associated with capital constraints in order to achieve a worthy outreach dimension. Hence, this study might recommend more capital injection into sharia cooperative in Kenya to increase its product suite, reduce the cost of operations, expand to the rural areas, and enhance confidence.

The results of this study show that more of the sharia cooperatives in Kenya are help underserved community members such as women, youth, and rural remote areas poor farmers. This implies that Kenya sharia cooperatives have achieved reasonable depth outreach but still more effort needed to reach the remote rural areas. Despite the more effort, more than $50 \%$ of the investigated samples indicate that the investigated cooperatives are not reached the efficient depth regard the underserved people as reflected in its policy. This might be due to the poor basic infrastructures and lack of capital to adopt wireless finance to improve its depth outreach. Almost all the sharia cooperatives in Keya have no enough capital to reach the required depth outreach although they are targeting the right depth such as women, youth, and poor rural farmers and livestock.

Although the customers have seen the cost of sharia cooperative services is reasonable, the cooperative staff have agreed the introduction of fintech might improve the cost outreach. Sharia Cooperatives clients are found did not differentiate between sharia and other conventional products and services. Awareness seminar in Sharia cooperatives financial services is highly recommended. The results show the high cost of attracting new clients. That might be due to the unused of the targeted communities the new means of connections such as webmail, internet, and smart devices. The fact that sharia cooperative clients in Kenya have very low knowledge of using 
the internet, ATM, debit card, and agency banking indicates that the clients incur high costs in participating in sharia cooperative services. Hence, it recommended that clients should exposure to high capacity building by the cooperative in order to have efficient cost outreach. The results of this study might help government, policy makers and Sharia Cooperatives institutions to draw an effective strategy to adopt financial technology, financial literacy and capacity building programs that help in promoting cooperatives institutions to serve financial underserved communities in Kenya.

\section{References}

http://allafrica.com/stories/201410140109.html

http://allafrica.com/stories/201604111061.html

http://bankelele.co.ke/2012/11/safaricom-cba-launch-mshwari.html

http://cbagroup.com/m-shwari/faqs/

http://en.afrikinfos.com/2014/01/25/kenyan-ministry-to-launch-shariah-compliant-co-operative-policy/https://w ww.microlinks.org/first-sharia-compliant-savings-and-credit-cooperative-kenya-supports-growth

http://hdr.undp.org/sites/all/themes/hdr_theme/country-notes/KEN.pdf

http://softkenya.com/cooperatives/cooperatives-in-kenya/

http://softkenya.com/cooperatives/history-of-cooperatives-SACCO-in-kenya/

http://softkenya.com/SACCO/SACCO-in-kenya/

http://www.africaneconomicoutlook.org/en/country-notes/east-africa/kenya/

http://www.businessdailyafrica.com/Corporate-News/Treasury-sees-number-of-banks-falling-to-30-/-/539550/28 00294/-/nf0gshz/-/index.html

http://www.comboni.org/risorse/allegati/1138.pdf

http://www.google.so/url?sa=t\&rct=j\&q=\&esrc=s\&source=web\&cd=3\&ved=0ahUKEwiItsPW8ujMAhWEJhoK

Hao-A3MQFggpMAI\&url=http\%3A\%2F\%2Fabhinavjournal.com\%2Fjournal\%2Findex.php\%2FISSN-232

0-0073\%2Farticle\%2FviewFile\%2F1016\%2Fpdf_235\&usg=AFQjCNHC618GoK1JLf8nq0-ld3rZzItA9w\&s ig2=RaFXiwUi0bU2FvegNqmCJw\&bvm=bv.122448493,d.bGg

http://www.industrialization.go.ke/images/downloads/history-and-organization-of-cooperative-development-and -marketing-sub-sector-in-kenya.pdf

http://www.industrialization.go.ke/index.php/downloads/123-history-and-organization-of-cooperative-developm ent-and-marketing-sub-sector-in-kenya

http://www.kba.co.ke/research-center/working-paper-series

http://www.sasra.go.ke/

http://www.sasra.go.ke/index.php/news-updates/speeches/87-list-of-SACCO-societies-licensed-to-undertake-dep osit-taking-SACCO-business-in-kenya-for-the-financial-year-ending-december-2016\#.VzbTu8tJIMw

http://www.standardmedia.co.ke/business/article/2000197433/chase-bank-placed-under-receivership-for-one-year

http://www.taqwaSACCO.co.ke/Taqwa\%20Brochure.pdf

http://www.uwcc.wisc.edu/pdf/CIR62.pdf

https://tuko.co.ke/21860-equitel-vs-m-pesa-five-features-that-may-end-safaricoms-dominance.html

https://www.mfw4a.org/kenya/financial-sector-profile.html

https://www.mfw4a.org/kenya/financial-sector-profile.html

https://www.youtube.com/watch?v=R-i2qObtzsE

\section{Copyrights}

Copyright for this article is retained by the author(s), with first publication rights granted to the journal.

This is an open-access article distributed under the terms and conditions of the Creative Commons Attribution license (http://creativecommons.org/licenses/by/4.0/). 